"Mircea cel Batran" Naval Academy Scientific Bulletin, Volume XIX - 2016 - Issue 1

Published by "Mircea cel Batran" Naval Academy Press, Constanta, Romania // The journal is indexed in:

PROQUEST / DOAJ / DRJI / JOURNAL INDEX / I2OR / SCIENCE LIBRARY INDEX / Google Scholar / Crossref /

Academic Keys / ROAD Open Access / OAJI / Academic Resources / Scientific Indexing Services / SCIPIO

\title{
STUDY ON THE CARBON MONOXYDE AND HC EMISSIONS GENERATED BY THE DIRECT INJECTION DIESEL ENGINES, RUNNING WITH BIODIESEL
}

\author{
Doru COSOFRET ${ }^{1}$ \\ Marian BUNEA ${ }^{2}$ \\ Marian RISTEA ${ }^{3}$ \\ ${ }^{1}$ PhDc eng, Military Technical Academy, Bucharest \\ ${ }^{2}$ Prof. dr. eng, Military Technical Academy, Bucharest \\ ${ }^{3}$ Assist. prof. dr. eng, „Mircea cel Batran” Naval Academy, Constanta
}

\begin{abstract}
Currently, the research results on the use of mixtures of biofuels with fossil fuels to power diesel engines are controversial in terms of reducing emissions of $\mathrm{CO}$ and $\mathrm{HC}$ which are contained in the exhaust gases of diesel engines. The diversity of the results is due to possibly different type of biodiesel used, the type of engine on which the tests were carried out and the methods and conditions for obtaining these results. Therefore, researches on regular diesel - biodiesel mixtures in various ratio is still a matter of study. In this regard, we conducted a laboratory study on a 4-stroke diesel engine, by using different mixtures $(10,15,20,25,30,40$ and 50\%) of diesel with biodiesel made from rapeseed oil. The study results reveals that the $\mathrm{CO}$ and $\mathrm{HC}$ emissions will decrease within creasing load. Also, the HC emissions and CO emissions when using mixtures of $10 \%$ and $15 \%$ are lower than the same emissions produced when the engine is powered with diesel.
\end{abstract}

Keywords: emissions, biodiesel, mixture, engine

\section{Introduction}

The carbon monoxide ad particulate matters are some of the chemical products generated when using fossil fuels on various internal combustion engines. It is also well known that these exhaust gasses products have a very dangerous potential for human health.

It can be easily foreseen that worldwide there is a necessity on reducing the overall emissions level. One potential method could be the usage of bio fuels for powering the internal combustion engines. Most of the studies are revealing the fact that the overall $\mathrm{HC}$ and $\mathrm{CO}$ emissions are lower than the normal way of fueling the engines; in the same idea, there are also some studies that are indicating an increased level of emissions. Xue e.a. developed an analysis of the published work and revealed that $84,4 \%$ of the studies are pointing a decreased level of $\mathrm{CO}$ emission and also $89,5 \%$ of studies are indicating a $\mathrm{HC}$ decreasing, by considering the same level of emissions, when powering the internal combustion engine with regular diesel oil.

\section{Material and method}

The study on the effects of biodiesel on $\mathrm{CO}$ and $\mathrm{HC}$ emissions was conducted on the Gunt CT159 Modular stand with a single cylinder engine of 2 kW, a HM 365 universal load and braking drive, which was connected to a computer with a program of data collection created for the platform and performed on the LabView core. (Fig.1) The MGT 5 type gas analyzer, together with the printer, was attached to the stand exhaust.

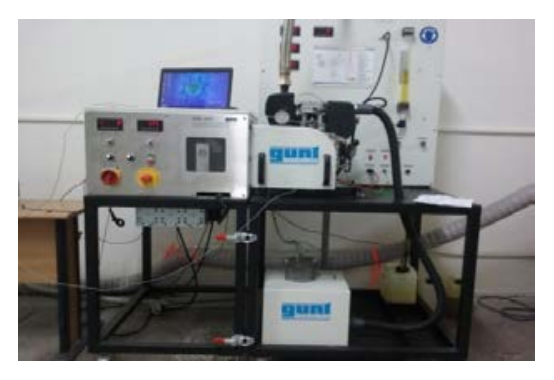

Figure 1. Gunt CT159 Modular stand

The engine characteristics on which the tests were carried out are shown in Table 1. The concentrations of NO could be determined by means of MGT 5 type gas analyzer. In order to carry out the tests, FIX 51 diesel was used (containing at least 5\% biodiesel) and rapeseed biodiesel, which were supplied by Rompetrol Midia - Năvodari refinery.

The main characteristics of the fuels used for the tests are shown in Table 2.

In order to carry out the laboratory tests, mixtures of biodiesel and diesel, in concentrations of 10 , 15,$20 ; 25 ; 30 ; 40$ and $50 \%$ were used. The resulting fuels were marked for identification, depending on the feedstock used, as follows: $M$ (100\% diesel - Euro-Diesel, Type 5); B10; B15; B20; B25; B30; B40 and B50 (biodiesel mixed with diesel). Mixtures with a proportion of 
"Mircea cel Batran" Naval Academy Scientific Bulletin, Volume XIX - 2016 - Issue 1

Published by "Mircea cel Batran" Naval Academy Press, Constanta, Romania /I The journal is indexed in: PROQUEST / DOAJ / DRJI / JOURNAL INDEX / I2OR / SCIENCE LIBRARY INDEX / Google Scholar / Crossref /

Academic Keys / ROAD Open Access / OAJI / Academic Resources / Scientific Indexing Services / SCIPIO

biodiesel of more than $50 \%$ were not used in tests because, according to the specialty literature, diesel engines have to withstand changes of the fuel system.

The tests were performed on the engine from the stand which was sequentially charged both with diesel and with mixtures obtained while there was no load on the engine $(2 \mathrm{Nm})$, but also when the engine had various loads: $3 \mathrm{Nm}, 4 \mathrm{Nm}, 5 \mathrm{Nm}, 7 \mathrm{Nm}$ and $8 \mathrm{Nm}$.

Table 1. Characteristics of the engine

\begin{tabular}{|l|l|}
\hline Engine type & Hatz 1B20-6 \\
\hline Manufacturer & GUNT Germany \\
\hline Cycle type & 4 stroke Diesel \\
\hline Speed & $2500[1 / \mathrm{min}]$ \\
\hline Power & $2[\mathrm{~kW}]$ \\
\hline $\begin{array}{l}\text { Number of } \\
\text { cylinders }\end{array}$ & 1 cylinder \\
\hline Aspiration type & Natural aspiration \\
\hline Cooling type & Air cooling \\
\hline Injection type & Direct injection \\
\hline Maximum torque & 8 Nm/2500l/min \\
\hline Cylinder bore & $69[\mathrm{~mm}]$ \\
\hline Piston stroke & $62[\mathrm{~mm}]$ \\
\hline Compression ratio & $21: 1$ \\
\hline
\end{tabular}

Table 2. Characteristics of the fuel

\begin{tabular}{|l|c|c|}
\hline $\begin{array}{l}\text { Fuel type I Chemical } \\
\text { properties }\end{array}$ & $\begin{array}{c}\text { Diesel } \\
\text { EFIX 51 }\end{array}$ & Biodiesel \\
\hline $\begin{array}{l}\text { Density at 15 o C (ISO } \\
\text { 3675) [Kg/m3] }\end{array}$ & 842,7 & 879.30 \\
\hline $\begin{array}{l}\text { Viscosity at 40oC (ISO } \\
\text { 3104) [mm2/s] }\end{array}$ & 3,1294 & 5,13 \\
\hline Cetane number & 51,5 & 60,1 \\
\hline Carbon concentration [\%] & 85.7 & 77 \\
\hline $\begin{array}{l}\text { Hydrogen concentration } \\
\text { [\%] }\end{array}$ & 13.3 & 12 \\
\hline Oxygen concentration [\%] & 0.923 & 11 \\
\hline $\begin{array}{l}\text { Sulphur concentration (ISO } \\
\text { 8754) [\%] }\end{array}$ & 0.077 & 0.0024 \\
\hline $\begin{array}{l}\text { Methyl esters content of } \\
\text { fatty acids [\%] }\end{array}$ & 5.6 & 100 \\
\hline
\end{tabular}

The real load points used to demonstrate the compliance must be of $\pm 5 \%$ of the rated output, in the selected duty point, apart from the case when the point of loading represents $100 \%$, where the range can be between 0 and $5 \%$. For example, at the point of loading of $75 \%$, the acceptable range is $70 \%-80 \%$ of the rated output [9].

\section{Results}

CO emissions. The carbon monoxide is one of the intermediary compounds that are produces in the intermediary combustion phase. The mechanism is depending by the fuel - air ratio, fuel type, combustion chamber design, injection timing and pressure and also injection velocity (Puneet, e.a., 2015). Figure 2 is emphasizing the CO emissions comparison when using regular diesel oil and biodiesel - diesel oil mixtures.

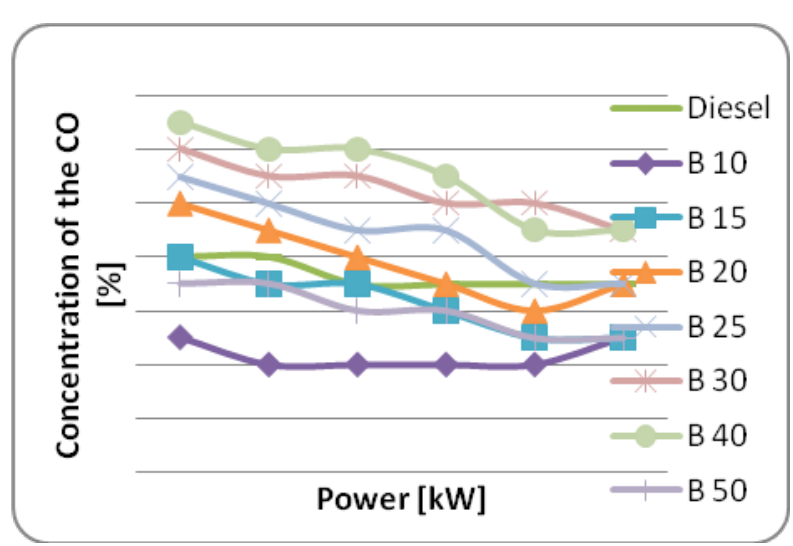

Figure 2. CO emissions versus engine load

The experimental results are showing that the $\mathrm{CO}$ emissions, when using biodiesel mixtures will be decreasing, together with engine's load. In the same time, there can be seen that, in the case of lox percentage mixtures (10\% and 15\%) CO emissions will be also reduced. This may be determined by the fact that, together with an increased load, the quality of air - fuel mixture will be increased and the air - fuel ratio will be higher, which will determine the conversion of $\mathrm{CO}$ emissions in CO2 emissions (Tesfa e.a, 2014; Xue e.a., 2011). In the case of low ratio mixtures, the $\mathrm{CO}$ emissions reduction is explained in the literature by the additional oxygen content in the biodiesel composition, which will burn more carbon molecules, and will increase the quality of combustion (Tesfa, e.a. 2014). In the same time, an increased level of $\mathrm{CO}$ emissions, when using high biodiesel content, is triggered by an increased viscosity level, which will drive to a lover fuel spray quality in the combustion chamber, with a bad influence on the fuel atomization process and also a poor combustion process (Sharma e.a., 2014). As a remark, it is obvious that the obtained experimental results are in accordance with the ones expressed in literature.

HC emissions. The incomplete combustion process of the fossil fuel and also the vaporizing process are the main $\mathrm{HC}$ emissions sources (Puneet e.a., 2015).

Figure 3 is presenting the $\mathrm{HC}$ emissions figures both when using regular diesel fuel oil and biodiesel mixtures.

The experimental results are emphasizing the fact that also the $\mathrm{HC}$ emissions levels will be dropping together with an increased engine load, due to an 
"Mircea cel Batran" Naval Academy Scientific Bulletin, Volume XIX - 2016 - Issue 1

Published by "Mircea cel Batran" Naval Academy Press, Constanta, Romania // The journal is indexed in:

PROQUEST / DOAJ / DRJI / JOURNAL INDEX / I2OR / SCIENCE LIBRARY INDEX / Google Scholar / Crossref /

Academic Keys / ROAD Open Access / OAJI / Academic Resources / Scientific Indexing Services / SCIPIO

optimized air - fuel mixture, together with engine's load (Tesfa e.a., 2014). It may be observed that, when looking at the experimental cases, the $\mathrm{HC}$ emissions are lower than the ones recorded when using only diesel fuel oil. Also, at maximum engine load, these emission levels will drop to null, excepting the B30 and B50 experimental cases. This result is generated by the higher oxygen content in the fuel mixture, which will increase the combustion process' quality, especially at high loads (Nantha Gopal e.a., 2014).

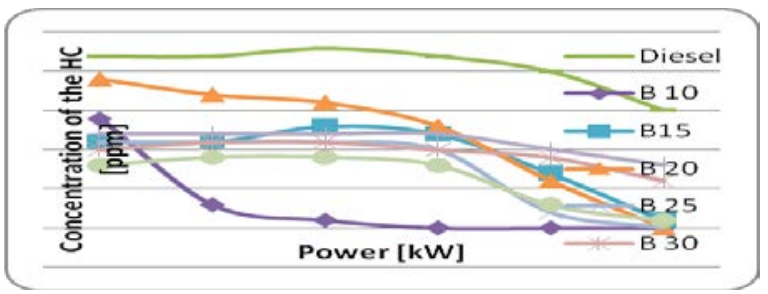

When studying the academic literature, it may be also observed a sudden emission drop, when using biodiesel mixtures (Xue e.a., 2011). It can also be concluded that the experimental results are valid, and aligning with the worldwide recognized results.

Figure 3. HC emissions versus engine load

\section{CONCLUSIONS}

The purpose of the experiment was to highlight the variation of $\mathrm{CO}$ and $\mathrm{HC}$ emissions in the exhaust gases depending on load, for a single cylinder diesel engine that was fueled with different concentrations of biodiesel $(10 \%, 15 \%, 20 \%$, and $25 \% 30 \%, 40 \%$ and $50 \%)$ in diesel fuel. The biofuel used during the test was rapeseed oil, which represents the most used biofuel in the European market (85\%).

After testing the following conclusions were revealed:

- $\mathrm{CO}$ and $\mathrm{HC}$ emissions will decrease together withload increasing,both for diesel and for mixturesof diesel with biodiesel.

- HC emissions are registering a better development for all biodiesel mixture samples, in comparison with the regular diesel fuel oil; at maximum load, the $\mathrm{HC}$ emissions are dropping near zero;

- When using low ratio biodiesel mixtures (10\% and 15\%) it was observed a major decrease of CO emissions.

The results obtained from the tests carried out are consistent with the results presented in the literature.

\section{BIBLIOGRAPHY}

Mixing biodieselwithdiesel fuel

[1]. Xue J., Grift T.E. și Hansen A.C. Effect of biodiesel on engine performances and emissions. Renew. Sustain. Energy Rev. 2011, Vol.15, pp.1098-1116.

[2]. Tesfa Belachew, Fengshou Gu, Rakesh Mishra and Andrew Ball. Emission Characteristics of a CI ngine Running with a Range of Biodiesel Feedstocks, Energies, 2014, vol.7, pp.334-350. www.mdpi.com/journal/energies.

[3]. Sharma S.K., Ankur Dixit, Priyanka Goyal, S. Maheshwari. A Technical Review of Biodiesel Fuel Emissions and Performance on Industrial and Automobiles Application. International Journal Of Modern Engineering Research (IJMER), 2014, Vol. 4 (1), pp. 26-32. http://docslide.us/engineering/a-technicalreview-of-biodiesel-fuel-emissions-and-performance-on-industrial-and-automobiles-application.html.

[4]. Nantha Gopa K.I, Arindam Pal, Sumit Sharma, Charan Samanchi. Investigation of emissions and combustion. Alexandria Engineering Journal, 2014, Vol 53, pp. 281-287.

[5]. Puneet Verma, M.P. Sharma. Performance and Emission Characteristics of Biodiesel Fuelled Diesel Engines. International Journal Of Renewable Energy Research, 2015, No.1, Vol.5, pp.245-250. 